\title{
Changes in permeability of the Nojima fault damage zone inferred from repeated water injection experiments
}

\author{
Yuichi Kitagawa ${ }^{1 *}$ and Yasuyuki Kano ${ }^{2}$
}

\begin{abstract}
In 1995, the Hyogoken-Nanbu earthquake (M 7.3) ruptured the Nojima fault, Awaji Island, central Japan. To investigate the recovery process of a fault zone after a large earthquake, repeated water injection experiments have been conducted every few years in an 1800-m-long borehole near the Nojima fault since 1997. In addition, the groundwater discharge rate and pressure have been observed in an 800-m borehole. From the resulting data, the macroscopic permeability of the fault fracture zone was estimated to range roughly from $1 \times 10^{-6}$ to $2 \times 10^{-6} \mathrm{~m} / \mathrm{s}$. The macroscopic permeability of the fault fracture zone decreased until 2003, and then, it stabilized or increased slightly through 2006. These changes in permeability indicate that the fault fracture zone stabilized within 8 years after the occurrence of the earthquake.
\end{abstract}

Keywords: 1995 Hyogoken-Nanbu earthquake, Nojima fault, Permeability, Water injection experiment, Healing

\section{Introduction}

When a large earthquake occurs on a fault, stress acting on the fault is released and rocks surrounding the fault are fractured. Thereafter, the fractured rocks are thought to recover physical properties, and then, stress begins to accumulate again, until the next earthquake. The Nojima fault, Awaji Island, central Japan, ruptured during the 1995 Hyogoken-Nanbu earthquake, which had a Japan Meteorological Agency magnitude $\left(M_{\mathrm{JMA}}\right)$ of 7.3. To investigate the recovery process of a fault zone just after a large earthquake, repeated water injection experiments have been conducted near the Nojima fault since 1997. The objective of the Nojima fault zone probe project is to study the properties and recovery processes of the fault zone (Ando 2001). Kitagawa et al. (2007) showed by groundwater observations that from 1997 to 2003 the permeability of the fractured zone near the fault decreased, and observations of crustal strain (Mukai and

\footnotetext{
*Correspondence: y-kitagawa@aist.go.jp

${ }^{1}$ Research Institute of Earthquake and Volcano Geology, Geological Survey of Japan, National Institute of Advanced Industrial Science and Technology, Tsukuba Central 7, 1-1-1 Higashi, Tsukuba, Ibaraki 305-8567, Japan

Full list of author information is available at the end of the article
}

Fujimori 2007) and self-potential (Murakami et al. 2007) during the same period supported their findings.

Other studies have investigated temporal changes in fault zones just after a large earthquake. For example, Vidale and Li (2003) used active seismic techniques to measure seismic wave velocity around the Johnson Valley fault, California, which ruptured during the 1992 Landers earthquake (M 7.3), and found that P-wave and $S$-wave velocities $<1 \mathrm{~km}$ from the fault trace increased after 1994 and that velocities in the fault zone decreased after the 1999 Hector Mine earthquake (M 7.1). Li et al. (2007) similarly observed the fault zone damage and healing associated with the 2004 M6 Parkfield earthquake. Xue et al. (2013) studied the tidal response of water levels in a borehole drilled through the Wenchuan earthquake fault zone in China and suggested that decreasing permeability in the fault zone might reflect the healing process.

Here, we report on the results of repeated water injection experiments conducted at the Nojima fault from 1997 to 2006, focusing on the temporal changes in the permeability of the fractured zone near the fault after 2003 , since the relative change in the permeability is more evidently estimated than the absolute value of that. 


\section{Methods: water injection experiments and observations}

Three boreholes were drilled to depths of 500, 800, and $1800 \mathrm{~m}$ near or into the Nojima fault and a branch fault during 1995-1996 (Ando 2001) (Fig. 1), immediately after the 1995 Hyogoken-Nanbu earthquake. In this area, the Nojima fault slipped more than $1 \mathrm{~m}$ and the Nojima branch fault slipped about $0.15 \mathrm{~m}$ during the earthquake (Awata and Mizuno 1998).

We insert the geological information in Fig. 1b, c (Ando 2001; Murata et al. 2001). The geology at this site is composed of the Osaka Group, the Kobe Group, and the Cretaceous Ryoke granitic rock. The water injection experiments were conducted in the 1800 -m borehole, which was drilled from a site east of the surface trace of the branch fault. This borehole penetrated the branch fault and reached the fractured zone of the Nojima fault. Several holes of the casing for the screen were made at 1596-1671 m depth by the perforation. A vertical array of seismographs was installed in the 1800-m injection borehole, and the vertical distribution of temperature was also observed every $1 \mathrm{~m}$ from the surface to $1460 \mathrm{~m}$ depth by use of an optical fiber cable (Yamano and Goto 2005). The $800-\mathrm{m}$ borehole was drilled vertically from another site east of the branch fault. Crustal strain was observed with a strainmeter at the bottom of the 800-m observation borehole (Mukai and Fujimori 2007). We observed the discharge rate until August 2000 and pressure of the groundwater since August 2000 within the 785- to 791-m depth interval of the $800-\mathrm{m}$ borehole, at which there is a casing in shallower than $785 \mathrm{~m}$ depth and a cementing inside the borehole for install of the borehole strainmeter in deeper than $791 \mathrm{~m}$ depth (Kitagawa et al. 1999). The 500-m borehole, which was drilled with an inclination to the vertical of $29^{\circ}$ from a site between the surface traces of the two faults, passed through the Nojima fault. Several holes of the casing for the screen were made at 302.2-304.8 $\mathrm{m}$ depth by the perforation. In this borehole, groundwater levels were observed, and electromagnetic measurements were taken at the bottom of the borehole. Both seismic (Nishigami et al. 2008) and self-potential observations were made at the surface around the 1800-m injection borehole (Murakami et al. 2007) during the water injection experiments. Water injection experiments were conducted in 1997, 2000, 2003, 2004, 2006, 2009, and 2013. From 1997 to 2009, water was injected into the top of the 1800-m borehole. At first, the experiment scheme was to inject water from the screen at 1596 to $1671 \mathrm{~m}$ depth of the $1800-\mathrm{m}$ borehole, though the vertical distribution of temperature in the borehole during these experiments showed that the injected water leaked out of the borehole at a depth of around $540 \mathrm{~m}$, but not at greater depths (Yamano and Goto 2005). In the 2013 experiment, therefore, a packer was installed at $559 \mathrm{~m}$ depth, and water was injected into the 1800-m borehole through the screen at 1596-1671 m depth (Nishigami and Research Group of Water Injection Experiment at the Nojima Fault 2014). In this paper, however, we discuss only the results of the water injection experiments conducted under similar conditions (i.e., excluding the 2013 experiment). Water pressure in the 800-m borehole was not successfully measured in 2009 because of a problem with the measurement system. Therefore, for this study we recomputed the results of the experiments conducted from 1997 until 2003, which differ from the permeabilities reported in Kitagawa et al. (2007), and added the results obtained during the 2004 and 2006 experiments; then, using the combined results, we investigated temporal changes in permeability of the fractured zone near the Nojima branch fault.

The groundwater discharge rate and pressure were observed in the $800-\mathrm{m}$ borehole, which was screened in the 785- to 791-m depth interval. The rock at that depth interval is granite. The water head in the 800 -m borehole is higher than the surface; thus, the borehole is an artesian well. Until August 2000, the top of the borehole was open, so the discharge rate from the borehole was measured (Kitagawa et al. 2007). In August 2000, the borehole was sealed, so after that the water pressure was measured in the borehole with a pressure gauge. We consider these water pressure data to be equivalent to groundwater level data, by dividing water pressure by the density of water and the gravitational acceleration. The criterion of the water level is defined as the top of the borehole. The discharge rate and water pressure were recorded every $1 \mathrm{~min}$. The discharge rate time series (Fig. 2) shows cumulative 1 - $\mathrm{h}$ values by integrating the 1 -min discharge rate once every hour. In April 2006, the borehole was temporarily opened and the pressure sensor was replaced; then, the borehole was resealed in August 2006. The conversion coefficient between water pressure and output voltage of the pressure sensor used until April 2006 was re-estimated by verification of the conversion coefficient of the water pressure sensor in the borehole, and then, the water pressure data from 2000 to 2006 were recomputed by using the conversion coefficient.

The resolution and stability of the discharge rate and pressure data from the 800-m borehole (Fig. 2) differed depending on the measurement method, and high-quality data were obtained by the improvement/replacement of the measurement system of discharge rate and water pressure. In all experiments, the groundwater discharge rate and pressure increased during the injections and then decreased as soon as the injections were stopped. The changes in the groundwater discharge rate and pressure associated with the injections differed in each 


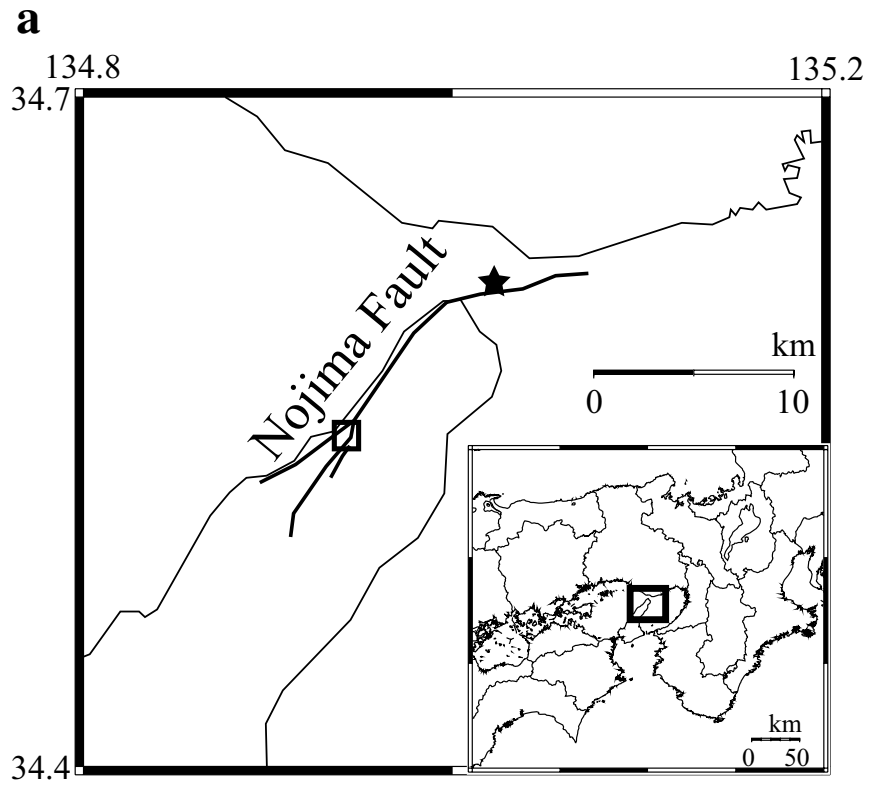

b
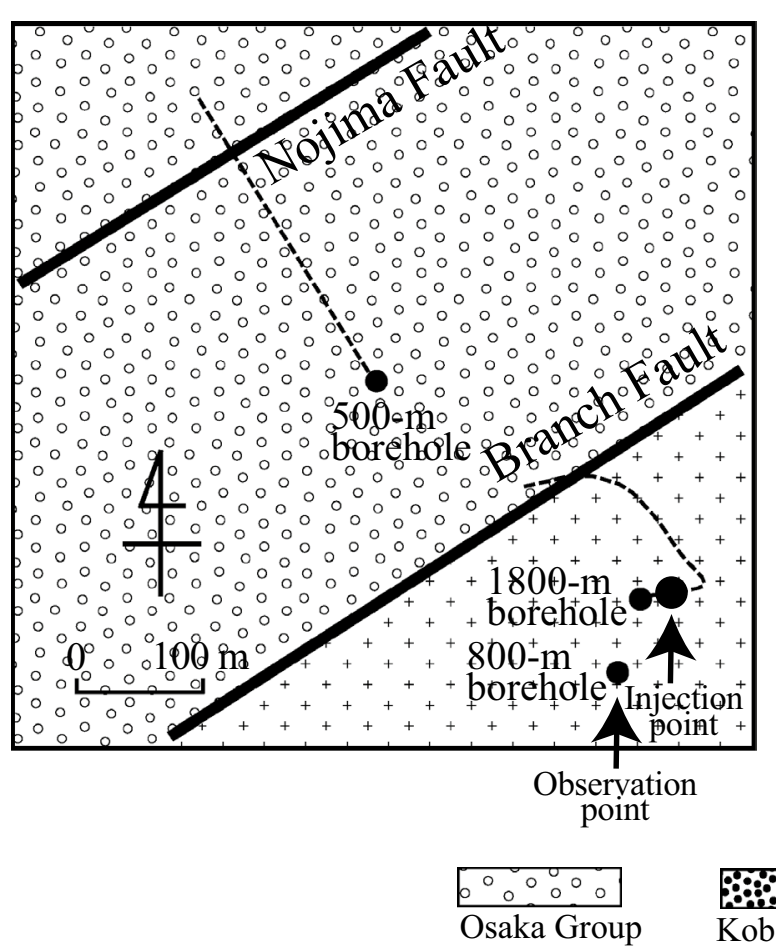

35.2

c

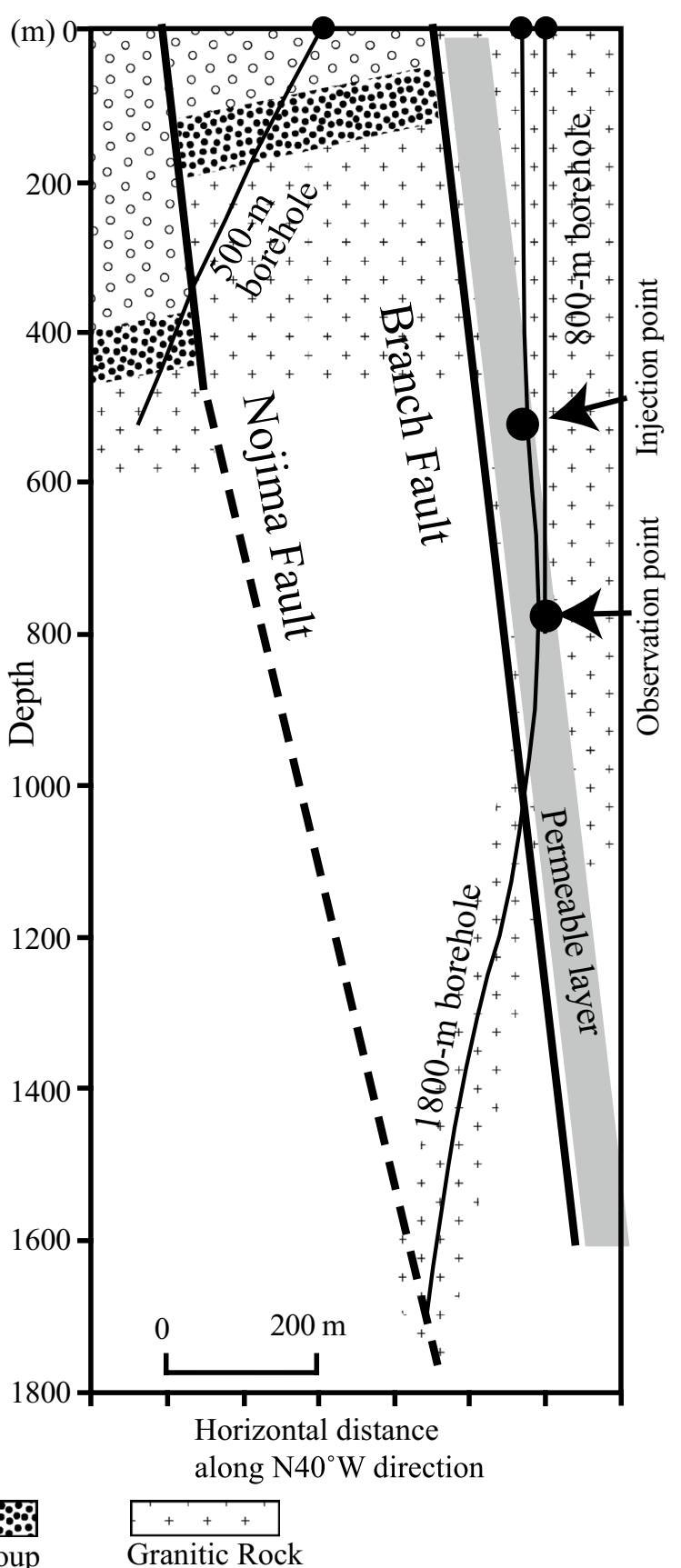

Fig. 1 a Map showing the locations of our observation site (square) and the epicenter of the 1995 Hyogoken-Nanbu earthquake (star). b Enlargement of the square in a showing the locations of the three boreholes and projections (broken lines) of the boreholes on the ground surface with a surface geological map. c Projection of the three boreholes on a vertical plane with a vertical geological cross section

experiment, depending on the injection rate and rock permeability during the experiment. The groundwater discharge and pressure data also show tidal responses, barometric responses, and long-term trends.
The discharge data are not directly comparable to the groundwater pressure data. Under the assumption that the relationship between the discharge rate and the groundwater level is proportional (e.g., Yuhara and 

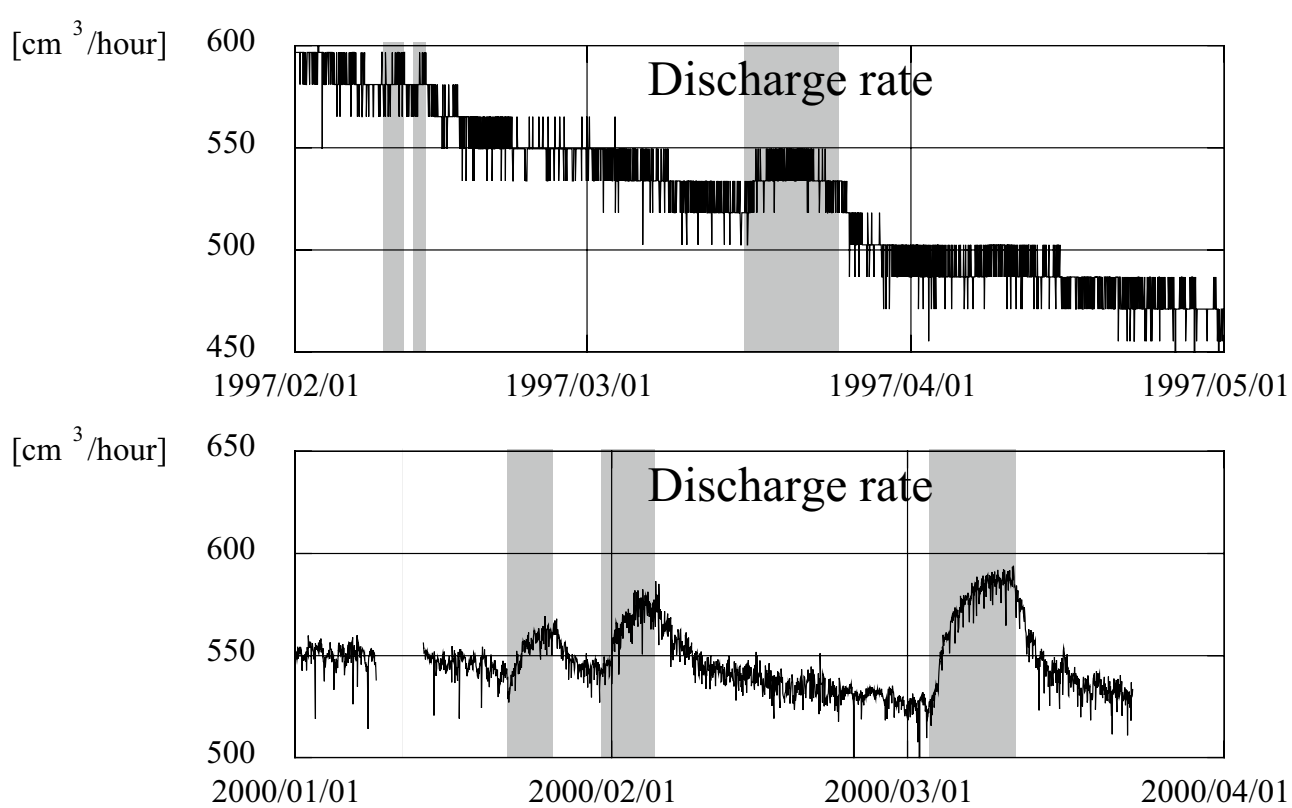

[m] 9.5

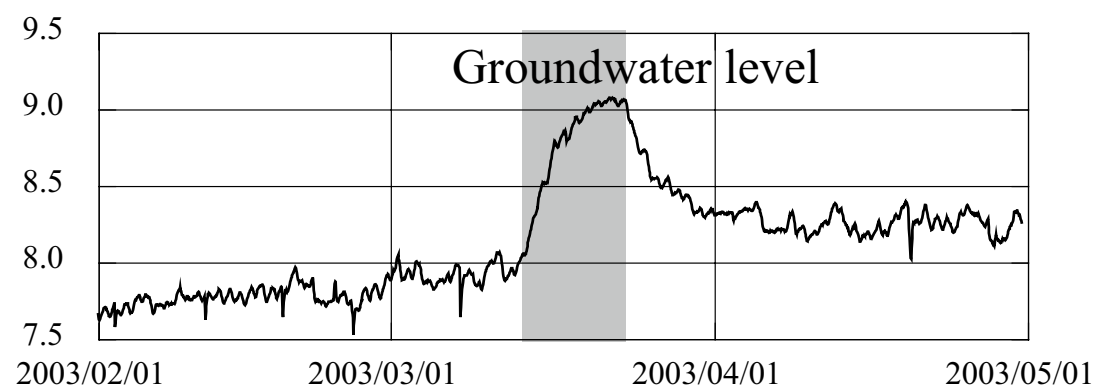

[m] 11.5

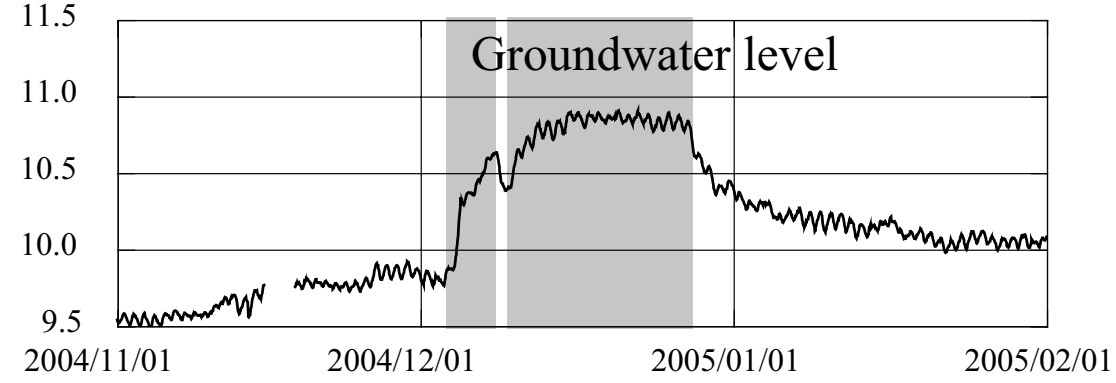

[m] 11.0

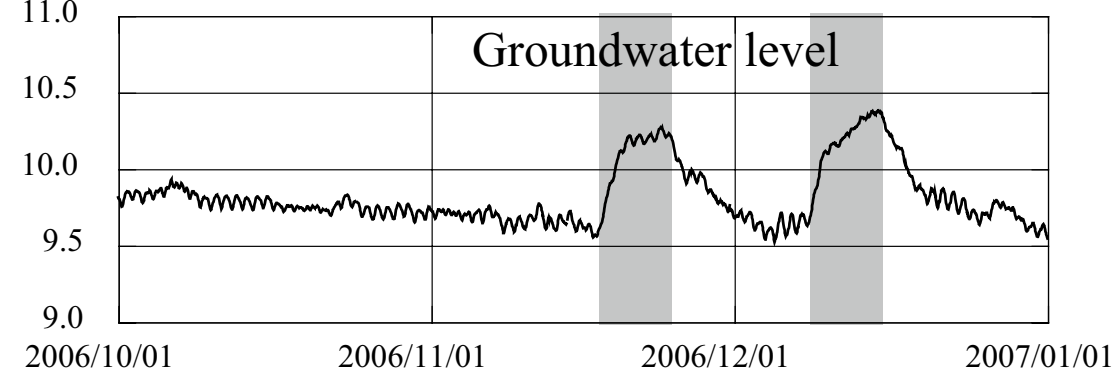

Fig. 2 Time series of observations of discharge and groundwater level in the 800-m borehole. The shaded bars show the periods of the water injection experiments 
Seno 1969), we estimated a conversion factor from the barometric responses of the groundwater discharge and pressure data, as described by Kitagawa et al. (2007), since period range of the barometric responses were similar to the duration time of the water injection experiments (Table 1). In 1997, the barometric response of the discharge was not estimated. The discharge data were used after they were converted to "groundwater level data" by using the conversion factor from the barometric responses of the groundwater discharge and pressure data. We used the converted discharge and pressure data during the experiments to estimate the permeability of the rock during each experiment (Fig. 3). To clarify those changes due to the experiment, the tidal and barometric responses and the linear long-term trend were removed from the discharge and pressure data time series. The tidal responses of the groundwater discharge and pressure data were removed using the tidal analysis program "BAYTAP-G" (Tamura et al. 1991). The barometric responses were removed by the operation of adding the 0.36 times for the discharge or 0.6 times for the pressure the barometric pressure data, based on Table 1. The linear long-term trend was estimated by the linear approximation method for the data around the time when each water injection experiment was done.

\section{Results: estimation of the permeability of the fault zone}

The structure around a fault has three components (Evans et al. 1997; Seront et al. 1998): the fault core, which includes the slip surface and usually has low permeability; the damage zone, which includes rocks fractured by fault slip and usually has high permeability; and the protolith, the undeformed bedrock (host rock), the permeability of which trends to be lower than that of the damage zone. All three components are likely present, parallel to the slip surface, along the Nojima branch fault (Mizoguchi et al. 2008); the fault core comprises fault gouge zone and fault breccia, the damage zone consists of fractured granite, and the protolith is undeformed granite. The fractured granite is $20 \mathrm{~m}$ thick (Mizoguchi et al. 2008) based on surface samples around this area, and the thickness of the permeable zone has been estimated to be 15-25 m (Lockner et al. 2009) based on core samples from a borehole drilled $4 \mathrm{~km}$ northeast of our study site. On the basis of these estimated thicknesses, we consider both the injection point in the 1800-m borehole and the open interval in the $800-\mathrm{m}$ borehole to be located in or near the damage zone of the Nojima branch fault (Fig. 1); thus, it is presumed that the injected water infiltrated into the damage zone.

We also estimated the permeability of the rock by using the numerical model and method described by Kitagawa et al. (2002, 2007). For simplicity, we considered the fault core and protolith to be impermeable and used a two-dimensional (2D) model for the permeable layer in the fractured granite. We assumed that the permeable layer was a homogeneous and isotropic vertical plane $5 \mathrm{~km}$ wide and $5 \mathrm{~km}$ deep with a uniform thickness of $50 \mathrm{~m}$. The layer is divided into 10,000 grid cells, each $50 \mathrm{~m} \times 50 \mathrm{~m} \times 50 \mathrm{~m}$ thick.

We used the finite difference method to calculate the pore pressure distribution in the rock from the injectioninduced flow rate with the finite difference form of the following 2D diffusion equation:

$$
\frac{\mathrm{d} H}{\mathrm{~d} t}=D\left(\frac{\mathrm{d}^{2} H}{\mathrm{~d} x^{2}}+\frac{\mathrm{d}^{2} H}{\mathrm{~d} z^{2}}\right)+F(Q),
$$

where $H(\mathrm{~m})$ is the head, equal to the pore water pressure plus the elevation; $D\left(\mathrm{~m}^{2} / \mathrm{s}\right)\left(=K / S_{\mathrm{s}}\right)$ is the hydraulic diffusivity of the permeable layer; $K(\mathrm{~m} / \mathrm{s})$ is the permeability (the hydraulic conductivity in a precise sense) of the permeable layer; and $S_{\mathrm{s}}(1 / \mathrm{m})$ is the specific storage of

Table 1 Estimates of the response of the groundwater discharge and pressure to the barometric pressure in the 800-m borehole

\begin{tabular}{|c|c|c|c|c|c|c|c|}
\hline \multicolumn{2}{|l|}{ Period of data } & \multirow{2}{*}{$\begin{array}{l}\text { Measured } \\
\text { parameter }\end{array}$} & \multirow{2}{*}{$\begin{array}{l}\text { Frequency } \\
\text { range of the } \\
\text { response } \\
\text { (cycles/day) }\end{array}$} & \multirow{2}{*}{$\begin{array}{l}\text { Response } \\
\text { to the } \\
\text { barometric } \\
\text { response }\end{array}$} & \multirow{2}{*}{$\begin{array}{l}\text { Standard } \\
\text { devia- } \\
\text { tion of the } \\
\text { response }\end{array}$} & \multirow{2}{*}{$\begin{array}{l}\text { Units of the } \\
\text { response }\end{array}$} & \multirow{2}{*}{$\begin{array}{l}\text { Conversion } \\
\text { factor }[\mathrm{cm} / \\
\left.\left(\mathrm{cm}^{3} / \mathrm{h}\right)\right]\end{array}$} \\
\hline From & To & & & & & & \\
\hline February 10, 2000 & March 2, 2000 & Discharge & $0.1-0.4$ & -0.360 & 0.048 & $\mathrm{~cm}^{3} / \mathrm{h} / \mathrm{hPa}$ & \\
\hline January 1, 2002 & June 30, 2002 & Pressure & $0.1-0.4$ & -0.510 & 0.074 & $\mathrm{~cm} / \mathrm{hPa}$ & 0.706 \\
\hline November 1, 2002 & February 28, 2003 & Pressure & $0.1-0.4$ & -0.573 & 0.144 & $\mathrm{~cm} / \mathrm{hPa}$ & 0.628 \\
\hline September 1, 2003 & November 30, 2003 & Pressure & $0.1-0.4$ & -0.628 & 0.027 & $\mathrm{~cm} / \mathrm{hPa}$ & 0.573 \\
\hline January 1, 2005 & June 30, 2005 & Pressure & $0.1-0.4$ & -0.587 & 0.042 & $\mathrm{~cm} / \mathrm{hPa}$ & 0.613 \\
\hline
\end{tabular}

The average conversion factor for converting discharge to water pressure was $0.63 \mathrm{~cm} /\left(\mathrm{cm}^{3} / \mathrm{h}\right)$ 
(a) Third in 1997

Corrected observation result

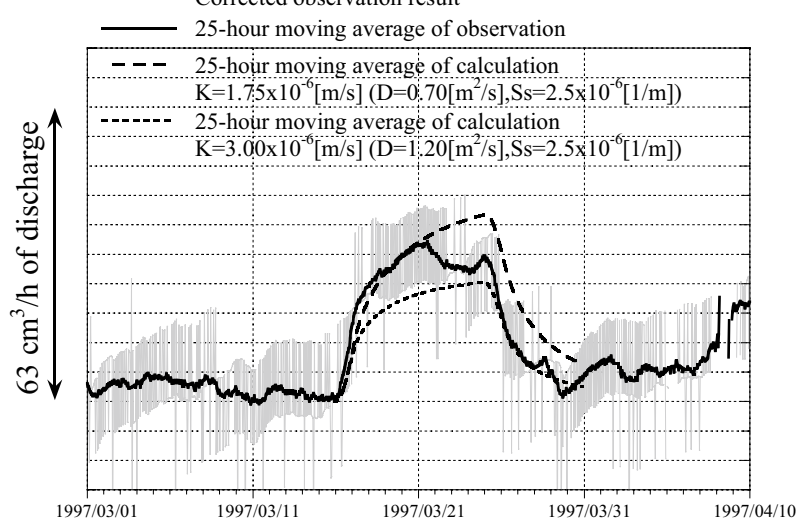

(c) Fourth in 2000

Corrected observation result

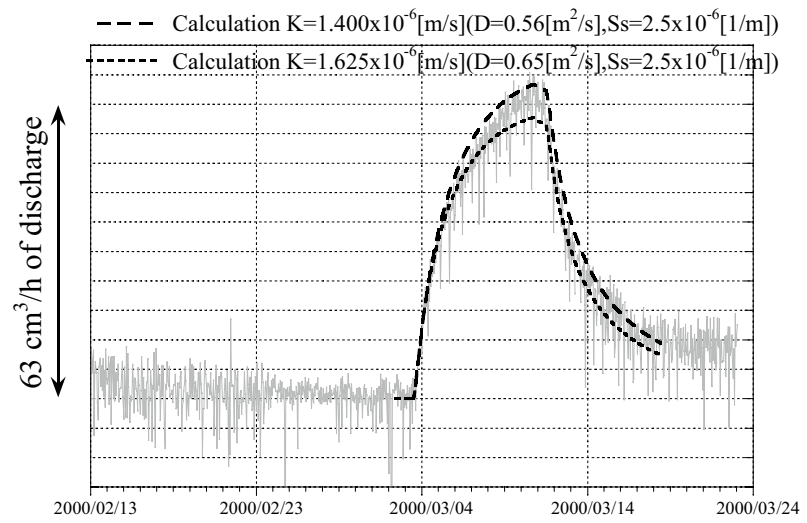

(e) First in 2004

Corrected observation result

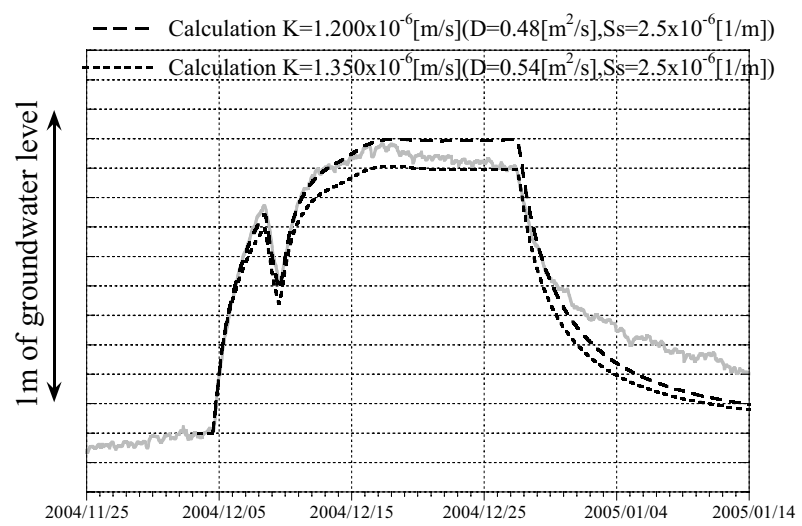

(b) Second and Third in 2000

Corrected observation result

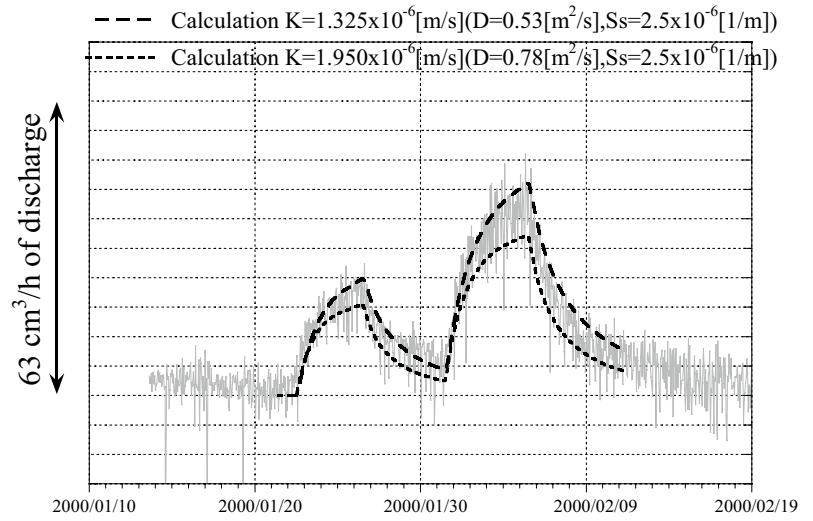

(d) First in 2003

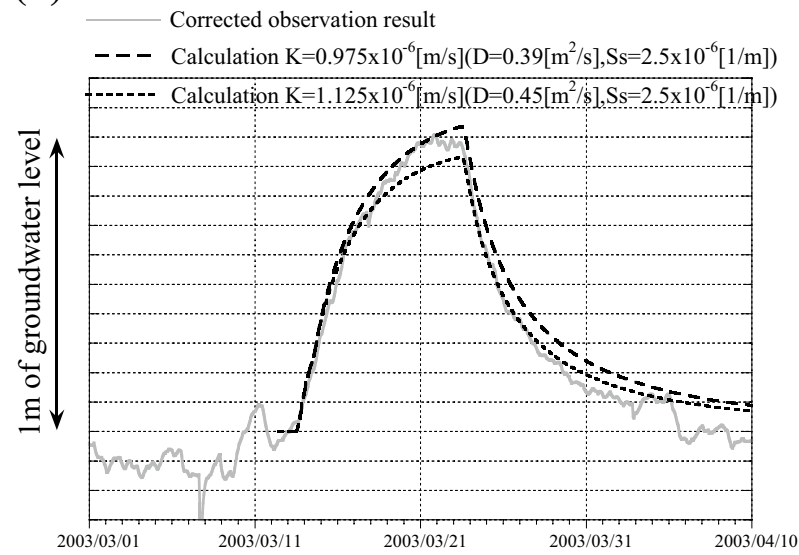

(f) First and Second in 2006

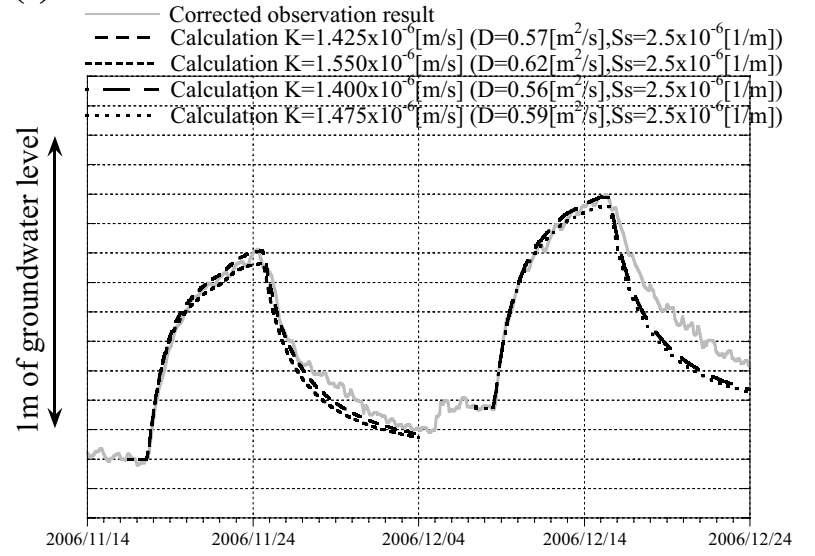

Fig. 3 Comparisons of the corrected observation results with the numerical calculations for each experiment. The corrected observation results were obtained by removing the tidal responses, barometric responses, and the linear long-term trend from the observed discharge and pressure data. a Third experiment in 1997, b second and third experiments in 2000, c fourth experiment in 2000, d first experiment in 2003, e first experiment in 2004, f first and second experiments in 2006 
the permeable layer. $F(Q)$, which represents the injection effect, is calculated as follows:

$$
F(Q)=\frac{Q(t)}{L^{3} S_{\mathrm{s}}},
$$

where $L(\mathrm{~m})$ is the size of one side of a grid $\left(\mathrm{m}^{3}\right)$ in this model and $Q(t)\left(\mathrm{m}^{3}\right)$ is the injection volume at the time of $t$. For the injection point during the experiments, we added $Q(t)$ by the approximated values of $Q(t)$. The upper boundary of the modeling domain is the ground surface, where the head is assumed to be constant, and the other boundaries are assumed to be impermeable. The injection point is the grid in the center of the modeling domain horizontally at the depth of $540 \mathrm{~m}$, and the observation point is the grid $70 \mathrm{~m}$ horizontally from the injection point at a depth of $790 \mathrm{~m}$.

Table 2 lists the hydraulic parameters estimated by using Eqs. (1) and (2) for the experiments in which discharge rate and water pressure were well measured (Fig. 3). In past calculation results (Kitagawa et al. 2007), $S_{\mathrm{s}}$ ranges roughly from $2 \times 10^{-6}$ to $3 \times 10^{-6} \mathrm{~m}^{-1}$. Here, we assumed $S_{\mathrm{s}}$ to be $2.5 \times 10^{-6} \mathrm{~m}^{-1}$. The calculated temporal changes in permeability are shown in Fig. 4. The calculated permeability of the rock decreased with time from 1997 to 2003, but after 2003, the calculated permeability apparently increased slightly. Kano et al. (2008) estimated that the hydraulic diffusivity of the Nojima branch fault is $<1.5 \mathrm{~m}^{2} / \mathrm{s}$ by using the barometric response of groundwater pressure in the $800-\mathrm{m}$ borehole. This value is consistent with the hydraulic diffusivity values listed in Table 2 . Although the estimated absolute values of hydraulic parameters depend on the structural model used, relative temporal changes in the permeability should be independent of the structural model on the basis of the hypothesis that the healing of the fault damage zone is temporally and spatially homogeneous. Thus, we can confirm that the macroscopic permeability of the damage zone stopped decreasing in 2003.

\section{Discussion}

As discussed by Kitagawa et al. (2007), Sato et al. (2000) and Tokunaga (1999) estimated that the permeability of the shallow crust of northern Awaji Island increased when the earthquake occurred. The decrease in permeability during the 8 years following the earthquake suggests that the earthquake-induced enhanced permeability in the fault fracture zone was approximating the state before the earthquake during that time.

The permeability estimated in this study is an order of magnitude less than that determined in 1996 in a borehole about $4 \mathrm{~km}$ northeast of the $800-\mathrm{m}$ borehole site, where the permeability of the Nojima fault zone was determined by hydrophone vertical seismic profiling (Kiguchi et al. 2001). Kiguchi et al. (2001) estimated the permeability of a $1-\mathrm{m}$-thick zone. Here, the permeable layer was modeled as a layer with a thickness of $50 \mathrm{~m}$. Therefore, if the actual permeable layer of the fault fracture zone is only a few meters thick, then the permeability of the actual permeable layer at our study site is probably similar to the previously reported permeability.

The permeability estimated here is orders of magnitude greater than permeabilities estimated in core samples (Mizoguchi et al. 2008; Lockner et al. 2009). It is difficult to obtain core samples for laboratory experiments that include the fracture or fractures primarily controlling the permeability; therefore, it is not surprising that permeabilities estimated for core samples are considerably smaller than permeabilities estimated by in situ testing for a granitic rock (Brace 1980).

$\mathrm{Li}$ and Vidale (2001) reported that the P-S-wave traveltime ratio decreased after the 1992 Landers earthquake and suggested that cracks near the fault zone were initially partly filled with fluid and became more fluid saturated with time after the earthquake. In the case of the Nojima fault zone, both the $800-\mathrm{m}$ and $1800-\mathrm{m}$ boreholes

Table 2 Macroscopic parameters of the fault fracture zone estimated by numerical calculations and fracture aperture widths calculated by assuming a simplified model with a single open fracture

\begin{tabular}{|c|c|c|c|c|c|c|c|c|c|}
\hline \multirow[t]{2}{*}{ Injection } & \multicolumn{7}{|c|}{ Macroscopic parameters of the fault fracture zone } & \multicolumn{2}{|c|}{ Single open fracture model } \\
\hline & $S_{s}(1 / m)$ & $\begin{array}{l}\text { Lower limit } \\
\text { of } D\left(\mathrm{~m}^{2} / \mathrm{s}\right)\end{array}$ & $\begin{array}{l}\text { Upper limit } \\
\text { of } D\left(\mathrm{~m}^{2} / \mathrm{s}\right)\end{array}$ & $\begin{array}{l}\text { Central } \\
\text { value of } K \\
(\mathrm{~m} / \mathrm{s})\end{array}$ & $\begin{array}{l}\text { Error of } K \\
(\mathrm{~m} / \mathrm{s})\end{array}$ & $\begin{array}{l}\text { Ratio to } \\
\text { 1997-3rd }\end{array}$ & $\begin{array}{l}\text { Error } \\
\text { of ratio }\end{array}$ & $\begin{array}{l}\text { Aperture } \\
(\mathrm{mm})\end{array}$ & $\begin{array}{l}\text { Error } \\
\text { of aperture } \\
(\mathrm{mm})\end{array}$ \\
\hline $1997-3 r d$ & $2.5 \mathrm{E}-06$ & 0.7 & 1.2 & $2.3750 E-06$ & $6.2500 \mathrm{E}-07$ & 1.0000 & 0.2632 & 0.522 & 0.047 \\
\hline $\begin{array}{l}2000-2 \text { nd } \\
\text { and } 3 \text { rd }\end{array}$ & $2.5 \mathrm{E}-06$ & 0.53 & 0.78 & $1.6375 E-06$ & $3.1250 \mathrm{E}-07$ & 0.6895 & 0.1316 & 0.463 & 0.030 \\
\hline $2000-4$ th & $2.5 \mathrm{E}-06$ & 0.56 & 0.65 & $1.5125 \mathrm{E}-06$ & $1.1250 \mathrm{E}-07$ & 0.6368 & 0.0474 & 0.452 & 0.011 \\
\hline $2003-1 s t$ & $2.5 \mathrm{E}-06$ & 0.39 & 0.45 & $1.0500 E-06$ & $7.5000 E-08$ & 0.4421 & 0.0316 & 0.401 & 0.010 \\
\hline $2004-1 s t$ & $2.5 \mathrm{E}-06$ & 0.48 & 0.54 & $1.2750 \mathrm{E}-06$ & $7.5000 \mathrm{E}-08$ & 0.5368 & 0.0316 & 0.427 & 0.008 \\
\hline $2006-1$ st & $2.5 \mathrm{E}-06$ & 0.57 & 0.62 & $1.4875 E-06$ & $6.2500 E-08$ & 0.6263 & 0.0263 & 0.450 & 0.006 \\
\hline $2006-2 n d$ & $2.5 E-06$ & 0.56 & 0.59 & $1.4375 E-06$ & $3.7500 E-08$ & 0.6053 & 0.0158 & 0.445 & 0.004 \\
\hline
\end{tabular}




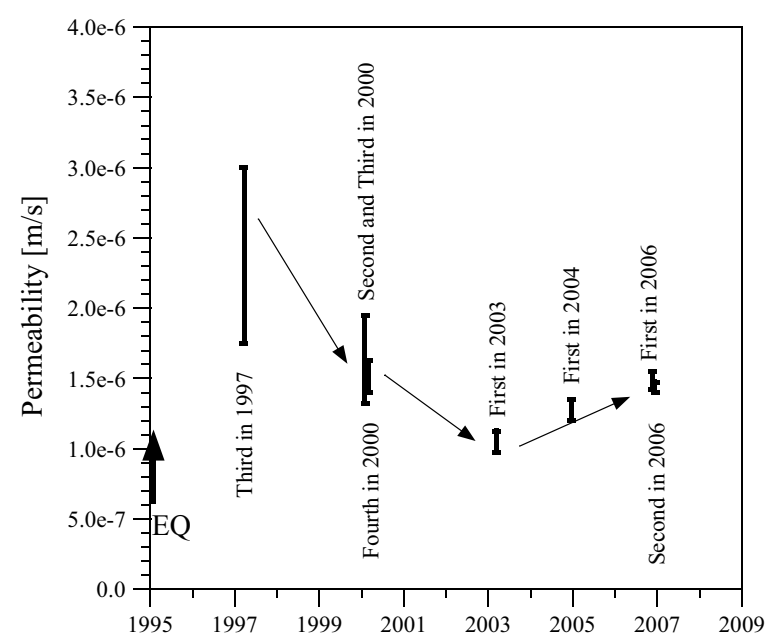

Fig. 4 Temporal changes in the macroscopic permeability of the fault fracture zone estimated by means of the water injection experiments. EQ indicates the occurrence of the earthquake

are artesian wells such that cracks must be fully saturated. In addition, an increase in water saturation in cracks reflects an increase in permeability to water. Therefore, an increase in water saturation probably cannot account for the decreased permeability 8 years after the earthquake.

We investigated whether the decrease in permeability was caused by temporal change in fracture apertures in the fractured granite by using a simplified model of a permeable layer with a single open fracture with a uniform aperture width. The permeability of the fracture in this model is expressed as follows (Domenico and Schwartz 1990):

$$
k=\frac{\rho_{\mathrm{w}} g b^{2}}{12 \mu},
$$

where $b(\mathrm{~m})$ is the hydraulic fracture aperture width, $\rho_{\mathrm{w}}$ is the density of water $\left(1000 \mathrm{~kg} / \mathrm{m}^{3}\right)$, g is gravitational acceleration $\left(9.80665 \mathrm{~m} / \mathrm{s}^{2}\right)$, and $\mu$ is the viscosity coefficient of water $\left(1 \times 10^{-3} \mathrm{~kg} / \mathrm{m} / \mathrm{s}^{2}\right)$. If it is assumed that water flows in a single open fracture, then the macroscopic permeability of the fracture zone, $K$, is expressed as

$$
K=\frac{k b}{L}=\frac{\rho_{\mathrm{w}} g b^{3}}{12 \mu L},
$$

where $L$ is the macroscopic width of the fracture zone.

If it is assumed that $L=50 \mathrm{~m}$, as described in "Results: estimation of the permeability of the fault zone" section, the hydraulic fracture aperture b can be calculated from the estimated macroscopic permeability (Table 2). Nakashima et al. (2010) measured fracture apertures in a granite sample under the barometric pressure in the laboratory and made a rough estimate that the fracture apertures were generally $<1 \mathrm{~mm}$ wide, and the average width was $0.39 \mathrm{~mm}$. Therefore, the aperture widths estimated here (Table 2) are consistent with the values reported by Nakashima et al. (2010). Given our assumption of a single open fracture with uniform aperture width, the decrease in permeability from 1997 to 2003 suggests that the fracture aperture decreased in width by $28 \%$. Actually, however, a number of fractures probably exist in the fractured granite zone. Therefore, some fractures may have decreased in aperture, and others may have closed or become clogged. The fracture aperture width seems to be associated with the strength of the fault rock. We have inferred that the decrease in permeability in the fault zone reflects the healing of the Nojima fault after the earthquake.

We could not identify a cause for the slight increase in permeability after 2003. Xue et al. (2013) reported that permeability in the Wenchuan earthquake fault zone in China was enhanced by the occurrence of remote earthquakes, and Kinoshita et al. (2015) suggested that the 2011 Tohoku earthquake caused enhanced permeability in a mine in central Japan. In the Nojima fault, there is no convincing evidence that the permeability enhancement was due to notable earthquakes. In general, an increase in normal stress (confining stress) reduces both fracture aperture widths and permeability (Baghbanan and Jing 2008). On the other hand, an increase in shear stress might cause permeability to increase and thus might imply the beginning of stress accumulation on the Nojima fault.

\section{Conclusions}

In an 800-m borehole near the Nojima fault, waterinjection-induced changes in the groundwater discharge rate and pressure were observed. On the basis of these changes, the macroscopic permeability of the fault fracture zone was estimated to range from $1 \times 10^{-6}$ to $2 \times 10^{-6} \mathrm{~m} / \mathrm{s}$. These permeabilities are less than values obtained by in situ testing at site about $4 \mathrm{~km}$ away, but we consider the difference to be small, given the simplified model assumed for the numerical calculation here. The macroscopic permeability of the fault fracture zone decreased from 1997 to 2003, after which it increased slightly. This decrease may correspond to a decrease in the width of fracture apertures in the fractured granite, or their closure. Permeability was enhanced when the earthquake occurred, and the subsequent decrease in permeability may reflect the recovery of the strength of the fractured granite in the fault zone after the earthquake.

\section{Authors' contributions}

Y. Kitagawa conducted the analysis and discussion of the data and prepared the manuscript. Y. Kano renewed the groundwater observation system and observed the groundwater at the 800-m borehole since 2006. Both authors read and approved the final manuscript. 


\section{Author details}

${ }^{1}$ Research Institute of Earthquake and Volcano Geology, Geological Survey of Japan, National Institute of Advanced Industrial Science and Technology, Tsukuba Central 7, 1-1-1 Higashi, Tsukuba, Ibaraki 305-8567, Japan. ${ }^{2}$ Research Center for Earthquake Prediction, Disaster Prevention Research Institute, Kyoto University, Gokasho, Uji City, Kyoto 611-0011, Japan

\section{Acknowledgements}

We thank K. Fujimori and A. Mukai for provision of the groundwater data at the $800-\mathrm{m}$ borehole from 2000 to 2006 . We thank K. Nishigami for conduct of the water injection experiments at the Nojima fault. We are grateful to three anonymous reviewers for valuable comments.

\section{Competing interests}

Both authors declare that they have no competing interests.

Received: 28 July 2016 Accepted: 9 November 2016

Published online: 21 November 2016

\section{References}

Ando M (2001) Geological and geophysical studies of the Nojima Fault from drilling: an outline of the Nojima Fault Zone Probe. IsI Arc 10:206-214. doi:10.1111/j.1440-1738.2001.00349.x

Awata Y, Mizuno K (1998) Explanatory text of the strip map of the surface fault ruptures associated with the 1995 Hyogo-Ken Nanbu Earthquake, central Japan — the Nojima, Ogura and Nadagawa Earthquake Fault, scale 1:10,000 tectonic map series (12). Geological Survey of Japan, Tsukuba, pp 44-49 (in Japanese)

Baghbanan A, Jing L (2008) Stress effects on permeability in fractured rock masses with correlated fracture length and aperture. Int J Rock Mech Min Sci 45:1320-1334. doi:10.1016/j.jirmms.2008.01.015

Brace WF (1980) Permeability of crystalline and argillaceous rocks. Int J Rock Mech Min Sci Geomech Abstr 17:241-251. doi:10.1016/0148-9062(80)90807-4

Domenico PA, Schwartz FW (1990) Physical and chemical hydrogeology. Wiley, New York

Evans JP, Forster CB, Goddard JV (1997) Permeability of fault-related rocks, and implications for hydraulic structure of fault zone. J Struct Geol 19:13931404. doi:10.1016/S0191-8141(97)00057-6

Kano Y, Kitagawa Y, Mukai A, Yanagidani T (2008) Permeability around the Nojima Fault detected using barometric response of pore pressure. In: Abstract of the 7th General Assembly of Asian Seismological Commission and the 2008 fall meeting of Seismological Society of Japan, X4-053

Kiguchi T, Ito H, Kuwahara Y, Miyazaki T (2001) Estimating the permeability of the Nojima Fault Zone by a hydrophone vertical seismic profiling experiment. Isl Arc 10:348-356. doi:10.1111/j.1440-1738.2001.00333.x

Kinoshita C, Kano Y, Ito H (2015) Shallow crustal permeability enhancement in central Japan due to the 2011 Tohoku earthquake. Geophys Res Lett 42:773-780. doi:10.1002/2014GL062792

Kitagawa Y, Koizumi N, Notsu K, Igarashi G (1999) Water injection experiments and discharge changes at the Nojima Fault in Awaji Island, Japan. Geophys Res Lett 26:3173-3176. doi:10.1029/1998GL005263

Kitagawa Y, Fujimori K, Koizumi N (2002) Temporal change in permeability of the rock estimated from repeated water injection experiments near the Nojima Fault in Awaji Island, Japan. Geophys Res Lett 29:121-1-121-4. doi:10.1029/2001GL014030

Kitagawa Y, Fujimori K, Koizumi N (2007) Temporal change in permeability of the Nojima fault zone by repeated water injection experiments. Tectonophysics 443:183-192. doi:10.1016/j.tecto.2007.01.012
Li YG, Vidale JE (2001) Healing of the shallow fault zone from 1994-1998 after the 1992 M7.5 Landers, California, earthquake. Geophys Res Lett 28:2999-3002. doi:10.1029/2001GL012922

Li YG, Chen P, Cochran ES, Vidale JE (2007) Seismic velocity variations on the San Andreas fault caused by the 2004 M6 Parkfield Earthquake and their implications. Earth Planets Space 59:21-31. doi:10.1186/BF03352018

Lockner DA, Tanaka H, Ito H, Ikeda R, Omura K, Naka H (2009) Geometry of the Nojima Fault at Nojima-Hirabayashi, Japan-I. A simple damage structure inferred from borehole core permeability. Pure Appl Geophys 166:16491667. doi:10.1007/s00024-009-0515-0

Mizoguchi K, Hirose T, Shimamoto T, Fukuyama E (2008) Internal structure and permeability of the Nojima fault, southwest Japan. J Struct Geol 30:513-524. doi:10.1016/j.jsg.2007.12.002

Mukai A, Fujimori K (2007) Secular change of permeability in the fracture zone near the Nojima fault estimated using strain changes due to water injection experiments. Tectonophysics 443:193-199. doi:10.1016/j. tecto.2007.01.023

Murakami H, Oshiman H, Yamaguchi S, Hashimoto T, Yoshimura R (2007) Time evolution of hydraulic and electrokinetic parameters around the Nojima fault, Japan, estimated by an electrokinetic method. Tectonophysics 443:200-208. doi:10.1016/j.tecto.2007.01.019

Murata A, Takemura K, Miyata T, Lin A (2001) Quaternary vertical offset and average slip rate of the Nojima Fault on Awaji Island, Japan. Isl Arc 10:360-367. doi:10.1111/j.1440-1738.2001.00334.x

Nakashima S, Hasegawa D, Yasuhara H, Kishida K (2010) Aperture measurement of granite fracture using microfocus $X$-ray CT system. Proc Symp Rock Mech 39:276-281 (in Japanese). http://library.jsce.or.jp/jsce/ open/00019/2010/39-0276.pdf

Nishigami K, Yamamoto K, Research Group of Water-Injection Experiments at Nojima Fault (2008) Generating properties of injection-induced earthquakes: repeated water-injection experiments in the Nojima fault zone. Abst AOGS, SE82-A039

Nishigami K, Research Group of Water Injection Experiment at the Nojima Fault (2014) Repeated Water injection experiments at the Nojima Fault: study on fault healing process and induced earthquakes. Earth Mon 36(3):130-138 (in Japanese)

Sato T, Sakai R, Furuya K, Kodama T (2000) Coseismic spring flow changes associated with the 1995 Kobe Earthquake. Geophys Res Lett 27:1219-1222. doi:10.1029/1999GL011187

Seront B, Wong TF, Caine JS, Forster CB, Bruhn RL, Fredrich JT (1998) Laboratory characterization of hydromechanical properties of a seismogenic normal fault system. J Struct Geol 20:865-881. doi:10.1016/ S0191-8141(98)00023-6

Tamura Y, Sato T, Ooe M, Ishiguro M (1991) A procedure for tidal analysis with a Bayesian information criterion. Geophys J Int 104:507-516. doi:10.1111/ j.1365-246X.1991.tb05697.x

Tokunaga T (1999) Modeling of earthquake-induced hydrological changes and possible permeability enhancement due to the 17 January 1995 Kobe Earthquake, Japan. J Hydrol 223:221-229. http://dx.doi.org/10.1016/ S0022-1694(99)00124-9

Vidale JE, Li YG (2003) Damage to the shallow Landers fault from the nearby Hector Mine earthquake. Nature 421:524-526. doi:10.1038/nature01354

Xue L, Li HB, Brodsky E, Xu ZQ, Kano Y, Wang H, Mori J, Si JL, Pei JL, Zhang W, Yang G, Sun ZM, Huang Y (2013) Continuous permeability measurements record healing inside the Wenchuan earthquake fault zone. Science 340:1555-1559. doi:10.1126/science.1237237

Yamano M, Goto S (2005) Long-term monitoring of the temperature profile in a deep borehole: temperature variations associated with water injection experiments and natural groundwater discharge. Phys Earth Planet Int 152:326-334. doi:10.1016/j.pepi.2005.04.010

Yuhara K, Seno K (1969) Onsengaku. Tijinshokan, Tokyo, pp 120-123 (in Japanese) 